\title{
Medya Destekli Öğretimin Hayat Bilgisi Dersinde Akademik Başarıya ve Öğrenmede Kalıcılığa Etkisi*
}

\author{
The Effects of Media-Supported Education on Academic \\ Success and Permanence of Learning in Social Studies Course
}

\author{
Eda BÜTÜN KAR**, Cevat ELMA***
}

Öz: Çalışmada “Medya Destekli Hayat Bilgisi Öğretim Programı”nın HayatBilgisi dersinde öğrenmeye ve akademik kalıcılığa etkisini belirlemek amaçlanmıştır. Bu amaçla Hayat Bilgisi dersi öğretim programı incelenerek kazanımlar belirlenmiştir. Belirlenen kazanımlara uygun olarak ders planları hazırlanmıştır. Ders planlarında temel öğretim aracı oarak medya araçları (video, şarkı, gazete kupürü, fotoğraf...) kullanılmıştır. Çalışma deney-kontrol gruplu ön test-son test ve kalıcılık ölçümlü desenlendiği için başarı testi hazırlanmıştır. Uygulanan ön test sonucunda deney ve kontrol grupları belirlenmiştir. Hazırlanan öğretim programı altı hafta, 24 ders saati süresince deney grubuna uygulanmıştır. Kontrol grubu ise standart eğitim-öğretim sürecine devam etmiştir. Öğretim programı tamamlandığında deney ve kontrol grubuna son test uygulanmıştır. Son test ilişkisiz örneklemler t testi sonucunda ise deney grubu ve kontrol grubu arasında deney grubu lehine anlamlı farklılık ortaya çıkmıştır. Çalı̧̧manın diğer bir boyutu ise öğretim programının öğrenmedeki kalıcıllğaetkisinin belirlenmesi yönündedir. Yapılan kalıcılık testi ilişkili örneklemler $t$ testisonucunda deney grubunun son test ve kalıc1lk testi arasında anlamlı bir farkll1ıkmeydana gelmediği görülmüştür. Kontrol grubu kalıcılık testi ilişkili örneklemler testi sonucunda ise kontrol grubunun son test ve kalıcılık testi puan ortalamalarıarasında son test puanları lehine anlamlı farklılık olduğu görülmüştür. Deney vekontrol grubunun kalıcılık testi ilişkisiz örneklemler $t$ testi sonucunda ise deneygrubu lehine anlamlı farklılık ortaya çıkmıştır. Yani "Medya Destekli Hayat Bilgisiöğretim Programı"nın öğrenme ve öğrenmede kalıcılık üzerinde olumlu bir etkiyaptığı söylenilebilir.

Anahtar Kelimeler: Hayat bilgisi, medya, medya destekli öğretim

\begin{abstract}
The aim of this study is to determine the effect of "Media-Supported Social Studies Education" on learning and academic permanence in Social Studies course. For this purpose, Social Studies lesson curriculum was examined and the learning outcomes were determined. Lesson plans were prepared in accordance with the determined these learning outcomes. Media tools (video, song, newspaper clippings, photographs ...) were used as the basic teaching tool in lesson plans. The study was prepared with testcontrol group, pre-test-post-test and permanency measurement test. Experimental and control groups were determined as the pre-test result. In this study, the curriculum prepared by researcher was implemented for 24 hours in 6 weeks. The control group continued to the standard education-training process. When the curriculum was completed, the post-test was performed on experiment and control groups. As a result of post-test irrelevant sample t-test, a significant difference was observed between experiment and control groups in favor of experiment group. Another aspect of this study is to determine the effect of education curriculum on the permanency of learning. As a result of permanency-test related samples t-test, it wasobserved that there was not a significant difference between post-test and permanency test of experiment group. As a result of permanency-test-related samples t-test, it was observed that there was a significant difference between post-test and permanency test of control group in favor of post-test scores. As a result of permanency-test-irrelevant samples t-test of experiment and control groups, it was found that there was a significant difference in favor of experiment group. In conclusion, it can be stated that "MediaSupported Social Studies Education" has positive effects on learning and permanency of learning. Keywords: Social studies, media effect, media supported teaching
\end{abstract}

\section{Giriş}

\footnotetext{
* Çalışma "Medya Destekli Öğretimin Hayat Bilgisi Dersinde Akademik Başarıya ve Öğrenmede Kalıcılığa Etkisi” adlı doktora tez çalışmasından üretilmiştir.

** Yrd. Doç. Dr., Sinop Üniversitesi, Eğitim Fakültesi, Sinop-Türkiye, e-posta: edabutun@ gmail.com

*** Doç. Dr., Ondokuz Mayıs Üniversitesi, Eğitim Fakültesi, Samsun-Türkiye, e-posta: cevatelma@gmail.com
} 
İlkokul eğitiminin amacı çocuğa yaşamda gerekli olan temel becerilerin verilmesidir. Bu beceriler anadil ve temel matematik eğitimi, toplumsal becerilerin kazandırılması ve çeşitli değerlerin benimsenmesi şeklinde açıklanabilir. Hayat Bilgisi dersi ise bu eğitim basamağının toplumsal değerler, doğa ve çevre bilinci, bireysel ilişkiler, geçmişe yönelik duyarlılık gibi birçok farklı yönünü oluşturmaktadır.

Hayat bilgisi dersinin amaçlarından biri de öğrencilerin iyi birer vatandaş olarak yetişmesinin temellerini atmaktır. İyi bir vatandaş, kendine sunulan bilgileri ve etrafinda olup bitenleri sorgulayan, eleştirel düşünebilen, yaşamla ilgili bilgi ve becerileri kazanmış, kazandığ bilgi ve becerileri karşılaştığ ${ }_{1}$ sorunlara uygulayabilen, karar verme ve entelektüel düşünme becerisi gelişmiş birey olarak tanımlanabilir (Farris, 2015; Sönmez, 2010; Tanrı̈ğen, 2005; Tekindal, 2005). İyi bir vatandaş hak ve sorumluluklarını bilen gerektiğinde bu bildiklerini kendisinin ve toplumun faydasına kullanabilmektedir.

Hayat Bilgisi dersinde çocuk kendini ve çevresini tanıyıp, kendini geliştirerek çevreye uyum sağlama, problem çözme gibi becerilerin temellerini oluşturur. Çocuk çevresi ve yaşamı ile ilgili ilk düşünceleri, duyguları ve hareketleri biçimlendirerek onları anlar, yorumlar, kestirir, ilke genelleme ve yöntemleri yeni olgularla kullanarak, analiz eder, yeni çözümler önerir ve değerlendirir (Belet, 1999, s. 78; Sözer, 2001, s. 28). Ayrıca ailesini, arkadaşlarını, vatanını sevebilme, iyi bir üretici ve tüketici olabilme, demokrasinin kurallarını benimseyebilme, çok boyutlu düşünebilme, bilimsel yöntemi kullanabilme gibi becerileri ilk olarak Hayat Bilgisi dersiyle kazanmaktadır. Hayat Bilgisi dersi ilkokulun ilk üç sınıfında çocuğun çevreye olan merakını gidermeye yönelik bir derstir (Demir, 2006, s. 11-12). Hayat Bilgisi dersi ile çocuğa yaşam boyu sürmesi amaçlanan üretkenlik becerisi kazandırılmaya çalışılmaktadır. Aynı zamanda bireye üretkenliği sağlayacak gerekli bilgi ve beceriyi edinme yolunu da öğretmeyi amaçlamaktadır. Böylece okul ortamı dışında da çocuğun başarılı olması hedeflenmektedir (Çakır, 2007, s. 19-20). Hayat Bilgisi dersi öğrencilerin aktif bir şekilde kendi öğrenmelerinin parçası olmasını amaçlar. Öğrenciler önceki bilgi ve deneyimlerini öğrenme sürecinde yapıtaşı olarak kullanmalıdırlar. Öğrenciler kendilerine yönelik pozitif bir alg1 olușturabilmelidir, kendilerini güvende, etkili ve yeterli hissetmelidir (Farris, 2015, s. 15). Hayat Bilgisi sosyoloji, psikoloji, antropoloji, tarih, ekonomi, coğrafya, felsefe gibi pek çok bilim dalından alıntılar yaparak bunları tek bir alanda birleştirir. Hayat Bilgisi, birçok konu ile ilgili doğruları, kavramları ve genellemeleri öğrenciye uygun seviyede aktarır. Birçok öğrenci, öğretmen konuyu doğru şekilde aktaramadığı için bu dersi sıkıcı ve ezberlenmesi gereken konular şeklinde görebilmektedir (Duplass, 2010, s. 6). Bu yüzden ders işleme sürecinde sadece ders kitaplarından değil, görsel ve işitsel materyallerden yararlanılması gerekmektedir. Ayrıca öğrencilerin de bu tür materyaller hazırlamaları desteklenerek, "yaparak-yaşayarak öğrenme”lerine firsat verilmelidir.

Hayat Bilgisi dersinde tüm bu kazanımların davranışa dönüşmesinde birçok araç kullanılabilmektedir. Ancak hem maliyet hem de ek bir donanıma gerek olmadan sınıf ortamında kullanılabilmesi nedeniyle ana materyal ders kitaplarıdır. İlkokulda çocuğun bulunduğu dönem itibarı ile dikkati kısa sürelidir ve çok çabuk dağılabilmektedir. Bu nedenle metinler ve etkinlikler hazırlanırken çocukların ilgisini çekebilecek, aktif olarak katılabilecekleri etkinliklere yer verilmelidir. (Kabapınar, 2007, s. 28-29; Köken, s. 2003: 18). Ayrıca Hayat Bilgisi kitaplarındaki metinler incelendiğinde genel olarak bir ögüt verme havası içinde olduğu görülmektedir. Ders kitabı yazarı ise öğrencilere sürekli makul olmayı ögütleyen gizli ses gibidir. $\mathrm{Bu}$ nedenle konuların ders kitaplarındaki işleniş şekli neden sonuç ilişkisi kurmadan doğruyu benimsetmeyi amaçlamaktadır (Kabapınar, 2002, s. 255-256). Ayrıca somut işlemler döneminde çocuklar kendilerine öğretilmek istenen ilke ve değerleri öğrenmekte güçlük çekmektedirler. Çünkü bu dönemde ilke ve değerler çocuklar için soyut kavramlardan öte bir anlam ifade etmemektedir. Bu nedenle kitaplarda verilen ögütler çocuklarda davranış değişikliğine yol açmamaktadır. Bu durumu ortadan kaldırmak için çocukların bu değer ve ilkelerin yer aldığı somut örneklerden faydalanması sağlanmalıdır (Köken, 2003, s. 18-19-20; Özdemir, 1998, s. 3). Böyleceçocuklar bu tür bilgileri hayatlarının hangi noktasında kullanabileceklerini öğrenebilmebilmekte, somut yaşantılar oluşturabilmektedir. $\mathrm{Bu}$ durum da öğrenilen bilgilerin kalıcılığının artmasını sağlamaktadır. 
Öğretimin sadece kitaplarla sınırlı kalmaması gerekliliğinin diğer bir nedeni kitaplarda yaratılan ideal dünyadır. Öğrenciler, kitaplardaki idealize edilmiş şekilde sunulan hayatı gerçekçi bulmamaktadır. Ayrıca kitaplardaki öykülerde sorunlar ders verici bir şekilde sonlandırılırken çocuğu düşünmeye, farklı çözüm yolları üretmeye teşvik edecek etkinliklere yer verilmemektedir (Kabapınar, 2002, s 255-256). Diğer bir unsur ise ders kitaplarının gelişen teknolojinin yanında zayıf kalmasıdır. Özellikle televizyon, internet, bilgisayar, tablet, akıllı telefon gibi teknolojik gelişmeleri yakından takip ettiği bilinen (RTÜK, 2013) yeni nesil için ders kitapları yeterli gelmemekte, öğrencilerin ilgisini çekmekte yetersiz kalmaktadır. Bu nedenle televizyon, bilgisayar, tablet gibi bilgi teknolojileri aracılığı ile medya tarafından sunulan ürünler çocukların zihninde çok daha kalıcı izler bırakabilmektedir. Medyada gördükleri bir fotoğraf, izledikleri bir haber çocuklar üzerinde çok daha etkili olabilmektedir (Aksaçlioğlu ve Yılmaz, 2007, s. 7-8; İrkin, 2012, s. 45-46; Kaya ve Tuna, 2008, s. 163-164; Tahiroğlu, Çelik, Bahalı ve Avc1, 2010, s. 26).Çünkü medya araçları bir olayı, bilgiyi sunmada birçok farklı aracı (ses, ışık, görüntü, dil ve anlatım) son derece etkili bir şekilde bileştirerek çarpıcı bir sunum için kullanabilmektedir. Böylece ileyici ya da okuyucular hem bilişsel hem de duygusal olarak etkilenebilmektedir.

Ders kitaplarının yaşanan teknolojik gelişmelere ayak uydurabilecek formda olmaması ve çocukların ilgisini çekmede yetersiz kalması Milli Eğitim Bakanlığını harekete geçirmiştir. Bakanlık tarafindan yapılan projeler ile çocukların kitaplar kadar bilgi teknolojilerinden de (bilgisayar, projeksiyon, internet, akıllı tahta, tablet) yararlanması desteklenmektedir (MEB, 2013). Böylece sınıf ortamında da bu tür teknolojilerin ve kitapların yanı sıra çocukların gerçek günlük hayat sorunları ile karşılaşabilecekleri medya ürünlerinin olumlu yönde kullanılması hem çocukların derse olan ilgisinin artmasını hem de öğretim sürecinin sadece kitaplarla sınırlı kalmayıp sınıf ortamında daha etkili bir öğretim sağlanmasını, sadece yazı ile aktarılması mümkün olmayan durumların görsel ve işitsel materyallerle aktarılmasını sağlamaktadır (Arslan ve Adem, 2010, s. 65-66; İşler, 2003; Karakaş ve Karaca, 2011, s. 352). Özellikle yurtdışında yapılan birçok çalışmada medyanın olumlu etkilerinden öğrenme ortamında yararlanıldığını görebilmekteyiz. Yapılan çalışmalarda çalışmalarda derste medya araçları kullanmanın dersi materyal açısından zenginleştirdiğini, öğrencinin dikkatini çekme ve öğrenciyi güdülemenin çok daha kolay hale geldiği belirlenmiştir (Purcell, Heaps, Buchanan ve Friedrich, 2013). Bir başka çalışmada derste medya araçları kullanmanın zor kavramların öğrenilmesini kolaylaştırdığını ortaya çıkmıştır (Holden ve Westfall, 2005). Medya araçlarının gerçek hayat durumlarını sınıfa taşımada etkili olduğu ve öğrencilerin algılama düzeylerini arrtırdığı ise bir başka çalışmanın sonuçları arasındadır (Berk, 2009; Knill, 2007). Ayrıca görsel ağırlıklı materyallerin okuma hızı düşük olan öğrencilerin okuduğunu anlamada destekleyici olduğu, ön bilgilerini harekete geçirmeyi kolaylaştırdığı belirlenmiştir (Kozma, 1994). Ülkemizde ise yapılan çalışmalar incelendiğinde medyanın olumsuz etkileri üzerinde yoğunlaşıldığı görülmektedir (Alver, 2005; Doğan, 2006; Doğutaş, 2013; Erjem ve Çağlayandereli, 2006; Karaaslan, 2015; Tahiroğlu, Çelik, Bahalı ve Avcı, 2010). Bu çalışma ile ülkemizde olumsuz etkisi sıklıkla vurgulanan medyanın eğitim sürecine olumlu şekilde katkı sağlaması amaçlanmıştır. Böylece sürekli benzer yönlerden eleştirilen medyanın ve medya araçlarının olumlu etkileri de vurgulanarak farklı bir bakış açısı kazandırılması amaçlanmıştır.

\section{Yöntem}

Araştırmada nitel ve nicel yöntemlerin bir arada kullanıldığ 1 karma araştırma yöntemi kullanılmıştır. Nitel ve nicel yöntemlerin birleştirildiği karma yöntem bu iki yöntemin güçlü taraflarını daha iyi vurguladığı için giderek daha tercih edilen bir yöntem haline gelmiştir (Östlund, Kidd, Wengstörm ve Rowa-Dewar, 2011, s. 369). Karma yöntem elde edilen verilerin derinlemesine analiz edilmesini sağlarken benzer verilerin birbirlerini desteklemesini, çelişen noktaların da daha belirgin şekilde vurgulanmasını sağlar. Böylece araştırmada daha derinlemesine ve kapsamlı çözümlemeler yapılabilmektedir. Ayrıca her iki yöntemin kullanılması araştırmanın araştırmacının yönlendirmesinden daha uzaklaşmasını sağlayarak çalışmanın tarafsızlığını arttırmaktadır. Bu çalışmada karma yöntemlerden biri olan açıklayıcı desen kullanılmıştır. Açıklayıcı desen önce nicel verilerin toplandığı sonrasında nicel verilerin nitel 
verilerle desteklendiği araştırma yöntemidir (Creswell, 2003, s. 12; Creswell ve Plano Clark, 2007, s. 81) Araştırmanın nitel ve nicel olmak üzere iki boyutu bulunmaktadır. Araştırmanın nicel boyutunda "Medya Destekli Hayat Bilgisi Öğretim Programı"nın etkisini belirlemek amacıyla deney-kontrol gruplu, başarı ve kalıcılık ölçümlü deneysel model kullanılmaktadır. Çalışmanın nitel boyutunda ise öğrencilerin öğretim programına yönelik düşünceleri ve tutumları görüşme ve gözlemlerle belirlenmeye çalışılmıştır.

Araştırmanın nitel ve nicel olmak üzere iki boyutu bulunmaktadır. Araştırmanın nicel boyutunda "Medya Destekli Hayat Bilgisi Öğretim Programı"nın etkisini belirlemek amacıyla deney-kontrol gruplu, başarı ve kalıcılık ölçümlü deneysel model kullanılmaktadır. Çalışmanın nitel boyutunda ise öğrencilerin öğretim programına yönelik düşünceleri ve tutumları görüşme ve gözlemlerle belirlenmeye çalışılmıştır. Araştırmanın bağımsız değişkenini öğrencilere uygulanan öğretim programı oluşturmaktadır. Bağımsız değişkenin bir boyutunu deney grubuna uygulanan "Medya Destekli Hayat Bilgisi Öğretim Programı" oluştururken diğer boyutunu ülke genelinde tüm 3. sınıf öğrencilerine geleneksel şekilde uygulanan öğretim programı oluşturmaktadır. Araştırmanın bağımlı değiş̧kenini ise öğrencilerin akademik başarıları ve öğrendikleri bilgilerin kalıcılığı oluşturmaktadır.

\section{Çalışma grubu}

Araştırmanın çalışma grubunu 2013-2014 eğitim öğretim yılında Samsun ili Havza ilçesinde öğrenim göre 31 üçüncü sınıf öğrencisi oluşturmaktadır. Çalışma grubu belirlenirken amaçlı örneklem yöntemi kullanılmıştır. Amaçlı örneklemde Çalışma grubunu oluşturacak olan okulların belirlenmesinde amaçsal örneklem yöntemlerinden benzeşik örnekleme kullanılmıştır. Benzeşik örneklemenin kullanılmasındaki amaç, birbirine benzer çevrede bulunan öğrencilerin Hayat Bilgisi dersine yönelik akademik başarılarının incelenmesidir. Öğrencilerin sosyo-ekonomik çevrelerine yönelik olan bilgiler öğretmen ile yapılan görüşmeler ve her sene başında doldurulan ögrenciler hakkında ayrıntılı bilgi veren formlarla elde edilmiştir. Böylece deney ve kontrol grubunun olabildiğince denk şekilde belirlenmesi amaçlanmıştır.

\section{Veri toplama araçlart}

Başarı testi.Öğretim programında belirlenen kazanımların öğrenciler tarafindan ne düzeyde kazanıldığını belirlemek amacıyla başarı testi uygulanmıştır. Başarı testi soruları Hayat Bilgisi, Sosyal Bilgiler, Türkçe, Medya alanlarında uzmanlaşmış 5 akademisyene ve üç sınıf öğretmenine incelettirilmiştir. Yapılan incelemeler sonrasında verilen tavsiyeler doğrultusunda testte düzeltmeler yapılmış, geçerlik ve güvenirlik sağlamak amacıyla 336 öğrenciye uygulanmıştır. Başarı testinin KR20 güvenirlik katsayısı 0,85 olarak bulunmuştur. Yapılan faktör analizi sonrasında değerleri 0.30 ve üzeri olan sorular olduğu şekilde kullanılmış, 0.20 ve 0.30 arasındaki iki soru düzeltilerek kullanılmış, değeri 0.20'nin altında olan bir madde ise çıkarılmıştır. 41 soruluk başarı testine geçerlik ve güvenirlik çalışmaları sonunda 40 soruluk son hali verilmiştir. Çıkarılan madde sonucunda KR20 güvenirlik katsayısında değişiklik olmamıştır.Başarı testi "Medya Destekli Hayat Bilgisi Öğretim Programı"nda deney ve kontrol gruplarının denkleştirilmesinde ön test, programın etkililiğinin belirlenmesinde son test ve öğrenilen bilgilerin kalıcılığının ölçülmesinde kalıcılık testi olarak kullanılmıştır.

Öğrenci gözlem formu. Öğrencinin karşılaştığı bu yeni uygulamaya dönük olarak düşüncelerini belirlemek amaçlı yapılandırılmamış gözlem yöntemi kullanılmıştır. Gözlemler “Medya Destekli Hayat Bilgisi Öğretim Programı”nın uygulandığı ders saatlerinde yapılmıştır. Bu süreçte öğrencilerin derse olan ilgileri, katılım düzeylerindeki değişim, öğrencilerin kullanılan materyallere dönük duygu ve düşünceleri, birbirleri ile olan iletişimlerinin düzeyi gözlenmeye çalışılmıştır. Programın uygulanış sürecinde uygulayıcı tarafından öğrenciler gözlenmiş, ders sırasında ve ders bitiminde yapılan gözlemler not edilmiştir. Yapılan gözlemlere yönelik elde edilen sonuçlar öğrencilerle yapılan görüşmeleri desteklemek ya da ayrışan noktaları belirlemek amacıyla kullanılmıştır.

Görüşme soruları. Öğretim programı uygulandıktan sonra öğrencilerin uygulama hakkındaki görüşlerini belirlemek amacıyla birebir görüşmeler yapılmıştır. Görüşme soruları açık 
uçlu sorulardan oluşmaktadır. Görüşme soruları hazırlandıktan sonra 2 alan uzmanı akademisyen ve 2 sınıf öğretmenin görüşlerine sunulmuştur. Ayrıca görüşme soruları çalışma grubunundışındaki bir öğrenci ile görüşme yapılarak anlaşılırlık bakımından sınanmıştır. Bu ön görüşmelerin sonunda bazı düzeltmeler yapılmış ve ardından görüşmelere başlanmıştır. Görüşme soruları öğrencilerin öğretim programında yapılan etkinliklere yönelik görüşlerini, kullanılan materyaller hakkındaki görüşlerini, dersin işleniş sürecinde karşılaştıkları olumlu ve olumsuz durumları, öğretim programının uygulanması tamamlandıktan sonra normal eğitim öğretim sürecine yönelik düşüncelerini belirlemeyi amaçlamıştır. Çalışmanın bu bölümünde elde dedilen verilerin geçerlilik ve güvenirliğinin sağlanması öncelikle veri çeşitlenmesine gidilmiştir. Nitel veri toplama yöntemlerinden gözlem ve görüşme birlikte kullanılmıştır. Elde edilen veriler sürekli karşılaştırılmıştır. Ayrıca deney grubu öğrencileri ile uzun süreli etkileşim kurulmuştur. Elde edilen veriler yansız bir araştırmacıya daha sunularak tarafsız bir gözle incelenmesi sağlanmıştır. Yine nitel çalışmalarda ulaşılması zor olançalışma geçerliliğini sağlamak amacıyla yapılan görüşmelerde araştırmacı tarafindan tarafsız olmaya gayret edilmiş ve mümkün olduğunca ögrencileri yönlendirmekten kaçınılmıştır. Yapılan görüşmeler ses kayıt cihazı ile kayıt altına alınmış, öğrenciler ve aileleri görüşmeler öncesi bu konuda bilgilendirilmiştir.

\section{İşlem}

Ön test. "Medya Destekli Hayat Bilgisi Öğretim Programı"nın uygulanacağı grupların belirlenmesi amacı ile öğrencilere ön test olarak başarı testi uygulanmıştır. Ön test uygulaması ile bağımsız değişken dışında kontrol edilebilen diğer değişkenler açısından grupların denkleştirilmesi sağlanmıştır. Yapılan ön test sonucunda birbirlerine denk olan gruplar belirlenerek öğretim programının işlenişs sürecine geçilmiştir.

Programın işlem aşamaları. Öncelikle 3. sınıf Hayat Bilgisi kılavuz kitabında programın uygulanacağı tarihlerdeki Hayat Bilgisi dersi kazanımları belirlenmiştir. Kazanımların belirlenmesinden sonra kazanımlara uygunders planları ve etkinlikler hazırlanmış kazanımlara uygun olduğu düşünülen video, gazete kupürleri, slaytlar ve fotoğraflar seçilmiştir. 3. sınıf Hayat Bilgisi kılavuz kitabında kazanımların kazandırılması için önerilen süreler dikkate alınarak altıhaftalık ders planları hazırlanmıştır. Ön test sonucunda deney ve kontrol grupları belirlendikten sonra "Medya Destekli Hayat Bilgisi Öğretim Programı"nın uygulanması sürecine geçilmiştir. Çalışma planı Milli Eğitim Bakanlığı tarafindan belirlenen Hayat Bilgisi dersinin haftalık ders saatlerine uygun şekilde hazırlanmıştır. Öğretim programı haftada dört gün dört saat olmak üzere altı hafta, 24 oturumdan oluşmaktadır. Her bir oturum bir ders saati sürmüş̧ür. Uygulama sürecinde deney grubundaki öğrencilere yönelik gözlemler yapılmıştır. Programın sonunda ise deney grubu öğrencileri ile görüşmeler yapılmıştır.

Kontrol grubunda ise ders ve çalışma kitabına uygun şekilde geleneksel eğitim-öğretim çalışmasına devam edilmiş, farklı herhangi bir çalışma yapılmamıştır. Öğretim programı bitiminde ise deney ve kontrol grubuna son test uygulanarak öğrencilerin akademik başarıları arasında anlamlı bir farklılık olup olmadığı incelenmiştir. "Medya Destekli Hayat Bilgisi Öğretim Programı"nın uygulama sürecinin bitiminden altı ay sonra deney ve kontrol grubundaki öğrencilere programın öğrenme üzerindeki kalıcılığını değerlendirmek amacı ile kalıcılık testi uygulanmıştır.

Son test ve kalıcllı testi. Öğretim programı uygulandıktan sonra hem deney hem kontrol grubuna son test olarak başarı tesi uygulanmış, öğretim programının etkililiği belirlenmeye çalışılmıştır. Son test uygulandıktan altı ay sonra deney ve kontrol grubuna kalıcılık testi uygulanarak öğretim programının kalıcılığa olan etkisi değerlendirilmiştir.

\section{Verilerin analizi}

Ön test, son test ve kalıcılık testi verilerini analiz etmek için güvenirlik katsayısı 0.85 olan başarı testi kullanılmıştır. Başarı testinden elde edilen verileri analiz etmek için ilişkili ve ilişkisiz örneklemler $t$ testi kullanılmıştır. Nitel verileri analiz etmek için yarı yapılandırılmış görüşme ve gözlem formları kullanılmıştır. Nitel verileri analiz etmek için betimsel analiz tekniği 
kullanılmıştır. Deney grubuna ise araştırmacılar tarafından hazırlanan yarı yapılandırılmış görüşme soruları ile görüşmeler yapılmıştır. Deney grubu öğrencileri ile yapılan görüşmeler ses kayıt cihazı ile kaydedildikten sonra yazı dökülmüş, betimsel analiz tekniği ile görüşmeler analiz edilmiştir. Betimsel analiz görüşme soruları ile elde edilen verilerin belirli temalara ayrılarak yorumlandığı bir tekniktir. Çalışmada betimsel analiz yöntemi kullanıldığı için doğrudan alıntılara yer verilerek yorumlarda tarafsız ve tutarlı olunması gibi açılardan tarafsız uzman görüşüne başvurulmuştur.

\section{Bulgular}

Çalışmanın bu bölümünde deney ve kontrol grubunda yer alan öğrencilerin ön test, son test ve kalıcılık testlerinden aldıkları puanlara yönelik bulgulara yer verilmiştir. Ayrıca deney grubunda yer alan öğrencilerin "Medya Destekli Hayat Bilgisi Öğretim Programı"na yönelik görüşleri ve araştırmacının programın işleniş sürecinde öğrencilere yönelik gözlemleri bu bölümde yer almaktadır.

\section{Deney ve kontrol grubu öğrencilerinin ön test puan ortalamalarına ilişkin bulgular}

Araştırmaya katılan deney ve kontrol grubunda yer alan öğrencilerin başarı testi ön test puanlarına göre aralarında anlamlı farklılık olup olmadığı ilişkisiz örneklemler t testi kullanılarak analiz edilmiştir. Analiz sonuçlarına Tablo 1'de yer verilmiştir.

Tablo 1

Deney ve Kontrol Grubu Öğrencilerinin Ön Test Puanları Ilişkisiz Örneklemler t Testi Sonuçları

\begin{tabular}{llllllll}
\hline Test & Grup & $N$ & $\bar{X}$ & $S$ & $s d$ & $t$ & $p$ \\
\hline Başar1 testi & Deney & 15 & 28.40 & 5.20 & 29 & -1.286 & .209 \\
& Kontrol & 16 & 30.43 & 3.50 & & & \\
\hline
\end{tabular}

Tablo 1 incelendiğinde, araştırmaya katılan deney ve kontrol grubundaki öğrencilerin ön testte aldıkları puanlar arasında anlamlı bir fark olup olmadığını ortaya koymak için yapılan ilişkisiz örneklemler $t$ testi sonucuna göre, öğrencilerin başarı testinden aldıkları puanlar arasında istatistiksel açıdan anlamlı bir farklılık olmadığı görülmektedir. Bu nedenle deney ve kontrol gruplarının birbirine denk olduğu söylenebilir.

\section{Deney ve kontrol grubu öğrencilerinin son testten aldıkları puan ortalamalarına ilişkin bulgular}

Çalışmanın bu bölümünde deney ve kontrol grubu öğrencilerinin son test puan ortalamaları ilişkili ve ilişkisiz örneklem $t$ testi sonuçlarına ilişkin bulgular yer almaktadır.

Deney ve kontrol grubu öğrencilerinin son test puanları ilişkisiz örneklemler t testi sonuçları Deney ve kontrol grubunda yer alan öğrencilerin son testten aldıkları puanlara göre aralarında anlamlı farklılık olup olmadığı ilişkisiz örneklemler t testi kullanılarak analiz edilmiştir. Analiz sonuçlarına Tablo 2'de yer verilmiştir.

Tablo 2

Deney ve Kontrol Grubu Öğrencilerinin Son Test Puanları Ilişkisiz Örneklemler t Testi Sonuçları

\begin{tabular}{ccccccccc}
\hline Test & Grup & $N$ & $\bar{X}$ & $S$ & $s d$ & $t$ & $p$ & $\eta^{2}$ \\
\hline Başarı Testi & Deney & 15 & 36.66 & 4.18 & 29 & 2.192 & .03 &. .133 \\
& Kontrol & 16 & 33.68 & 3.36 & & & & \\
\hline
\end{tabular}

Araştırmaya katılan deney ve kontrol grubundaki öğrencilerin başarı testinden aldıkları puanlar arasında istatistiksel açıdan deney grubu lehine anlamlı farklılık olduğu görülmektedir $[t(29)=2.192, p<.05)]$. Deney grubunun yapılan $t$ testi sonucunda daha yüksek puan aldığı yapılan istatistikler sonucunda ortaya çıkmıştır. Test sonucunda hesaplanan etki büyüklüğü $\left(\eta^{2}=0.133\right)$ bu farkın yüksek olduğunu göstermektedir. 
Deney ve kontrol grubu ögrrencilerinin son test puanları ilişkili örneklem t testi sonuçları

Deney ve kontrol grubunda yer alan öğrencilerin başarı testinden aldıkları ön test ve son test puan ortalamaları arasında anlamlı bir fark olup olmadığını belirlemek için ilişkili örneklemler için t testi yapılmıştır. Analiz sonuçları Tablo 3'te verilmiştir.

\section{Tablo 3}

Deney ve Kontrol Grubu Öğrencilerinin Son Test Puanları Ilişkili Örneklemler t Testi Sonuçları

\begin{tabular}{lllllllll}
\hline Test & Grup & $N$ & Ön test $\bar{X}$ & Son test $\bar{X}$ & $s d$ & $t$ & $p$ & $\eta^{2}$ \\
\hline \multirow{2}{*}{ Başarı testi } & Deney & 15 & 28.40 & 36.66 & 14 & -8.857 & .00 & 0.27 \\
& Kontrol & 16 & 30.43 & 33.68 & 15 & -7.863 & .00 & \\
\hline
\end{tabular}

Tablo 3 incelendiğinde, başarı testinden alınan puanlar arasında hem deney grubundaki öğrencilerin puanlarında anlamlı bir artış olduğu $[t(14)=-8.857, p<.05)]$ hem de kontrol grubundaki öğrencilerin puanlarında anlamlı bir artış olduğu $[t(15)=-7.863, p<.05)]$ görülmektedir. Test sonucunda hesaplanan etki büyüklügü $\left(\eta^{2}=0.27\right)$ bu farkın büyük olduğunu göstermektedir.

\section{Deney ve kontrol grubunun kalıcılık testi puan ortalamalarına ilişskin bulgular}

Çalışmanın bu bölümünde deney ve kontrol grubu öğrencilerinin kalıc1lık puan ortalamaları ilişkili ve ilişkisiz örneklem $t$ testi sonuçlarına ilişkin bulgular yer almaktadır.

Deney ve kontrol grubu kalıcılık testi ilişkisiz örneklemler t testi sonuçları

Deney ve kontrol grubunda yer alan öğrencilerin başarı testinin kalıcılık testinden aldıkları puanlara göre aralarında anlamlı farklılık olup olmadığ ilişkisiz örneklemler $t$ testi kullanılarak analiz edilmiştir. Analiz sonuçlarına Tablo 4'te yer verilmiştir.

Tablo 4

Deney ve Kontrol Grubu Öğrencilerinin Kalıcılık Testi Ilişkisiz Örneklemler t Testi Sonuçları

\begin{tabular}{|c|c|c|c|c|c|c|c|c|c|}
\hline \multirow{2}{*}{$\begin{array}{c}\text { Test } \\
\text { Başarı Testi }\end{array}$} & Grup & & $N$ & $\bar{X}$ & $S$ & $s d$ & $t$ & $p$ & $\eta^{2}$ \\
\hline & Deney & 15 & & 36.26 & 4.52 & 29 & 2.569 & .01 & 0.17 \\
\hline & Kontrol & 16 & & 32.56 & 3.46 & & & & \\
\hline
\end{tabular}

Araştırmaya katılan deney ve kontrol grubundaki öğrencilerin son testte aldıkları puanlar arasında istatistiksel açıdan anlamlı bir farklılık olduğunu görülmektedir $[t(29)=2.569, p<.05)]$. Test sonucunda hesaplanan etki büyüklüğ̈̈ $\left(\eta^{2}=0.17\right)$ bu farkın yüksek olduğunu göstermektedir.

Deney ve kontrol grubu öğrencilerinin kalıcılık testi iliş̧kili örneklemler t testi sonuçları Deney ve kontrol grubunda yer alan öğrencilerin başarı testinden aldıkları son test ve kalıc1lık test puan ortalamaları arasında anlamlı bir fark olup olmadığını belirlemek amacıyla ilişkili örneklemler için t testi yapılmıştır. Analiz sonuçları Tablo 4.3.2' de verilmiştir.

Tablo 5

Deney ve Kontrol Grubu Öğrencilerinin Kalıcılık Testi Ilişkili Örneklemler Için t Testi Sonuçları

\begin{tabular}{lllllllll}
\hline Test & Grup & $N$ & $\begin{array}{l}\text { Son } \\
\text { test } \bar{X}\end{array}$ & Kalıcıllk test $\bar{X}$ & sd & $t$ & $p$ & $\eta^{2}$ \\
& & & & & & & \\
\hline Başar1 & Deney & 15 & 36.66 & 36.26 & 14 & 1.871 & .08 & .007 \\
testi & Kontrol & 16 & 33.68 & 32.56 & 15 & 4.137 & .00 & \\
\hline
\end{tabular}


Tablo 5 incelendiğinde, Bașarı Testinden alınan puanlar arasında deney grubundaki öğrencilerin puanlarında anlamlı bir artış olmazken $[t(14)=1.871, p>.05)]$ kontrol grubundaki öğrencilerin puanlarında anlamlı bir düşüş olduğu $[t(15)=4.137, p<.05)]$ görülmektedir. Test sonucunda hesaplanan etki büyüklüğü $\left(\eta^{2}=0.007\right)$ şeklinde belirlenmiştir. Bu bulgu farkın küçük olduğunu göstermektedir.

\section{Medya destekli Hayat Bilgisi öğretim programına yönelik öğrenci görüşleri}

Çağımızda meydana gelen birçok değişikliğe rağmen kitaplar sınıflarda halen birincil ders materyali olarak kullanılmaya devam etmektedirler. Bunun öncelikli nedenlerinin başında ders kitaplarının maliyetlerinin düşük olması ve herhangi bir ek donanıma gerek olmadan sınıf ortamında kullanılabilecek olmasıdır. Günümüzde artık kitapların içindeki bilgiyi öğrenciye çok farklı şekillerde aktarabilecek birçok araç bulunmaktadır. Bilgi teknolojisi olarak da adlandırılan bu araçlar hem bilginin çok farklı şekillerde sunulmasını sağlarken hem de öğrencilerin severek takip ettikleri araçlar olmaları bakımından da öğretmene avantaj sağlamaktadırlar. Öğrencilerin derse olan güdülenmesi dersteki başarılarını olumlu yönde etkilemektedir. $\mathrm{Bu}$ nedenle öğrencilerin özellikle ilgisiz oldukları derslerde öğrencinin tutumunu olumlu yönde etkileyecek etkinliklere yer verilmeye çalışılmalıdır.

\section{Öğrencilerin öğretim programında yer alan etkinliklere yönelik görüşleri}

"Medya Destekli Hayat Bilgisi Öğretim Programı" uygulanırken öğrenciler farklı bir uygulama ile karşı karşıya kalmışlardır. Programın uygulanma sürecinde bilgi kaynağı olarak video, fotoğraf ve gazete gibi birçok medya aracı kullanılmaya başlanmıştır. Öğrencilerin dersin işleniş sürecindeki değişikliğe yönelik düşünceleri derse olan ilgilerini de olumlu ya da olumsuz yönden etkileyebilmektedir. Bu nedenle öğrencilerin yapılan etkinliklere yönelik düşünceleri önem taşımaktadır.

Geleneksel eğitim-öğretim süreci devam ederken gerekli olduğunda kullanılan video, fotoğraf gibi araçlar "Medya Destekli Hayat Bilgisi Öğretim Programı" uygulanırken artık dersin vazgeçilmez bir parçası haline gelmiştir. Nasıl ki geleneksel eğitim sürecinde kitaplar dersin vazgeçilmez bir unsuru ise "Medya Destekli Hayat Bilgisi Öğretim Programı"nın uygulanma sürecinde de dersin ana materyalleri haline gelmiştir. Özellikle gazetelerin derslerde kullanılmak için nadir tercih edilen bir araç olduğu düşünülürse öğrencilerin bu tür farklılıklara yönelik farkındalıkları önem taşımaktadır. Böyle bir ders işleme sürecinde öncelikli durum öğrencilerin bu değişimi fark edip etmediği ve bu değişim hakkında olumlu düşünceler taşıyıp taşımadıklarıdır.

Deney grubundaki öğrencilerin uygulama hakkındaki görüşlerini almak amacıyla ile birebir yapılan görüșmelerde öğrencilerin Hayat Bilgisi dersinin işleniş sürecindeki kullanılan materyallerdeki değişikliği fark ettikleri anlaşılmaktadır. Ayrıca öğrencilerin kullanılan tüm bu araçlara yönelik olarak son derece olumlu tutum içinde oldukları görülmektedir. Yapılan görüşmelerde öğrencilerin kullanılan araçları da son derece iyi hatırladıkları görüşmelerde verdikleri örneklerden de anlaşılmaktadır:

"Derste videolar ve gazete haberleri vardl, sonra internetten bir şeyler izlemiştik. Çok güzeldi...”(Ö1)

"Fotoğraflar, gazeteler falan vardl, haberler... Çok sevdim, zaman çok güzel geçti." (Ö2)

"Videolar, fotoğraflar, haberler gördük, güzeldi..." (Ö4)

"Filmler izledik, çok beğendim, hiç sıkllmadım." (Ö6)

"Gazeteler, videolar kullandik. Hoşuma gitti, çok beğendim. ” (Ö11)

Sınıf içinde farklı materyaller kullanmak öğrencinin derse dikkatini çekmek için en etkili yöntemlerden biridir. Ancak bu materyallerin öğrencinin dikkatini çektiği gibi ulaşılmak istenilen hedefin önüne geçmemesi, konuyu dağıtmaması gerekmektedir. Bu tür araçlar öğrencilerin derse yönelik tutumunu ve derse katılımlarını olumlu yönde etkilemektedir. Ayrıca öğrenciler etkinlikleri severler ise derse daha fazla katılmakta bu durum farklı fikirlerin ortaya konulmasında 
etkili olmaktadır (McKay, 2012, s. 70-71-72; Schoenfeld, 2002, s. 19-20). Bu nedenle derste materyal kullanmak kadar materyal seçimi de ayrı bir önem taşımaktadır.

Yapılan çalışmada öğrencilerin derste kullanılan medya destekli materyalleri ilgi çekici buldukları görülmektedir. Kullanılan bu materyaller öğrencinin derse yönelik güdülenmesini ve dikkatinin çekilmesi sürecini kolaylaştırmıştır. Ayrıca kullanılan materyallerin öğrenci tarafından sevilmesi öğrencinin derse olan ilgisini olumlu yönde etkilemiştir. Simo ve diğerleri (2010) ile Hsin-Yih (2000) tarafindan yapılan çalışmalarda da derste medya ürünleri kullanmanın derse yönelik ilgi ve motivasyonun arttırılmasında etkili olduğu belirlenmiştir.

Araştırmacı tarafindan yapılan gözlemlerde ise her Hayat Bilgisi dersi öncesinde öğrencilerin tekrar bu tür etkinlikler yapılıp yapılmayacağı yönünde sorular sorması, öğrencilerin bu tür etkinliklere yönelik olumlu düşünceler içinde olduklarının bir göstergesidir. Bunun yanında Hayat Bilgisi dersi daha çok kitaptan konuyu okuma ve karşılıklı konuşma şeklinde ilerleyen bir derstir. Bu nedenle özellikle dikkat süresi kısa olan ve okuma hızı yavaş olan öğrencilerin dikkati çok çabuk dağılmaktadır. Bu durum öğrencilerin derste ya sürekli uyarılmasını gerektirmektedir. Bunun sonucunda da dersin bölünmesi ve diğer öğrencilerin dikkatinin dağılmasına durumuyla karşı karşıya kalınmaktadır. Bu nedenle farklı etkinliklerle öğrencilerin dikkatinin canlı tutulması için "Medya Destekli Hayat Bilgisi Öğretim Programı"nda öğrencilerin dikkat süreleri de dikkate alınarak kısa videolar ve kısa haberler tercih edilmiştir. Böylece bir ders süresinde pek çok farklı materyal kullanma imkânı doğmuş ve öğrencilerin dikkati canlı tutulabilmiştir. Ayrıca birden fazla araç kullanılması konuya farklı açılardan yaklaşılmasına zemin hazırlamışır. Özellikle ders esnasında ilgisi çok çabuk dağılan öğrencilerin bile fikir üretmeye çabalamaları araştırmacı açısından en dikkat çekici sonuçlardan biri olmuştur. Bu durumun sağlanmasında en önemli etkenlerden birinin de derste kullanılan olayların öğrencilerin günlük hayatlarına çok yakın olaylardan seçilmesine yönelik olduğu düşünülmektedir. Böylece öğrenciler olayları kendi günlük yaşamıyla bağdaştırabilmiş, doğru ya da yanlış fikir üretmeye çalışabilmişlerdir.

\section{Öğrencilerin öğretim programında kullanılan materyallere yönelik görüşleri}

"Medya Destekli Hayat Bilgisi Öğretim Programı"nda videolar, gazete kupürleri ve fotoğraflar kullanılmıştır. Yapılan görüşmelerde kullanılan bu materyallerden öğrencilerin dikkatini en çok hangisinin çektiği, öğrencilerin en çok hangi tür materyalleri kullanmayı sevdikleri belirlenmeye çalışılmıştır.

Yapılan görüşmelerde öğrencilerin en çok videoları izlemekten zevk aldıkları belirlenmiştir. Öğrencilerin videoları gazete haberlerine tercih etmelerinde birden fazla faktör etkili olmaktadır. Bunlardan biri videoların hem göze hem kulağa hitap edebilmesidir. Ayrıca öğrenciler gazetelerin de yazılı araçlar olması sebebiyle kitaplara benzediklerini belirtmişler, okumayı sıkıcı bulduklarını ifade etmişlerdir. Ayrıca öğrenciler zaman zaman okudukları şeyleri daha önce görmedikleri için zihinlerinde canlandıramadıklarını, videoların bu imkânı onlara sağladıklarını belirtmişlerdir. Öğrencilerin okumayı zor ve zahmetli bulması, videoların ise sadece izlemeye yönelik araçlar olması öğrencilerin videolara yönelik tercihte bulunması konusunda etkili olmaktadır. Ayrıca videolar izlenirken bilgisayar, projeksiyon gibi teknolojik araçlar kullanılması öğrencilerin videolara olan tutumunu olumlu yönde etkileyen unsurlar arasında görülmektedir. Öğrenciler görüşlerini aşağıdaki şekilde dile getirmişlerdir:

"Hepsi güzeldi ama videolar daha güzeldi. Görsel olduğu için orada aklinda canlandırmaya çalışmıyorsun. Daha önce pandomim yapan birini görmemiştim. Pandomimle beden dili çok benziyomuş, daha unutmam sanirım." (Ö1)

"Videoları sevdim çünkü videodakiler her şeyi anlatarak yaptyor. Onu inceletiyor. Kitaplardan daha çok hoşuma gitti çünkü kitaplardan daha güzel anlatmış. ” (Ö2)

"En çok videoları sevdim. Internetten Dünya'y izlemek çok güzeldi. Karaları ve suları gerçekten görmek... İzlemek güzel, okumak bazen sılkıı oluyor." (Ö4)

"En çok videoyu sevdim. Videolar aklımda kaldı. Deprem videosunda kuklalar çok etkileyiciydi. Depremde alacağımız önlemleri çok güzel anlattı. Çok hoşuma gitti, hiç sikılmadım." (Ö5) 
"Filmler falan izledik. Başkalarının eşyalarını korumayı öğrendik çizgi filmden, büyürken ne kadar değiştiğimizi gördük. Önceden hep sadece kitaplardan okuyorduk. Şimdi okuduklarımı gösterdiniz öyle daha güzel oldu. Çok hoşuma gitti. Gazete haberleri kitap gibi geldi." (Ö6)

"Videoları sevdim. Kitaplar da güzel ama bir şeyler izlemek çok eğlenceli oluyor. Doğal afetleri görmek çok etkileyiciydi. Daha önce tsunami ve hortum görmemiştim, ülkemizde olmadığı için. Okurken bazen çok sikıliyorum." (Ö7)

"En çok izlediğimiz videoları çok sevdim. Mesela Atatürk'ün tüm eşyalarını müzede görebildik. Canlısını görmek daha güzel olurdu ama imkânım olmadĭ̆ı için böyle görebildim. Zaten gitmeyi çok istiyordum. Videolar sanki daha iyi açıklyyor. Böyle izlerken anlatması beni çok etkiliyor, duygulanıyorum. Kitaplar çok yeterli değil.” (Ö8)

"Videoları sevdim. Kitaplar yani aslında ben kitap okumayı da çok sevmiyorum. Mesela gazete okumayı da sevmiyorum haberleri seçiyorum içinden." (Ö9)

"Videoları sevdim, bilgisayarla işlemek çok zevkli. Ama gazete haberleri de ev kazalarının zararlarını anlattığı için etkileyiciydi. Çok dikkatli olmamız gerektiğini bir kez daha anladım." (Ö10)

"Bilgisayarda bir şeyler izlemek, yapmak çok güzel. Her şeyi onda görüyoruz. Dünya'yı karaları, suları gördük mesela... Kitaplarda sadece anlatıyorlar ama yazıları canlandıramıyorum. Gazeteler sanki kitap gibi onları çok sevmedim. Kitaplardan okuyalım ama videolarla canlandiralım." (Ö11)

"Videoları sevdim. Atatürk'ün eşyalarını görmüss oldum, yaptıklarını bir kez daha hatırladım. Videoları izlemek daha güzel çünkü daha kolay. Gazete haberlerini ise biraz sevdim, kitap gibiler" (Ö12)

"Videolart çok sevdim ögretmenim çünkü hem eğlendirici hem bilgi verici. Gazete haberlerini çok sevmedim çünkü okumak zorundayız." (Ö13)

"Videoları çok sevdim çünkü çok anlatıyor, çok güzel şeyler var. Atatürk müzesi. Atatürk'ün eşyaların daha önce görmemişstim görmüş oldum. Yapmamamı gereken davranışları ögrendik." (Ö14)

"Videoları sevdim. Dünya'yla ilgili izlediğimiz videolar çok güzeldi. Dünya ya nasıl zarar verdiğimizle ilgili video, karalar sular çok etkileyiciydi. Hem bilgisayar da kullaniyoruz, anlatılanları izlemiş oluyoruz. Görmediğim şeyleri görmüşs oldum." (Ö15)

Öğrencilerden biri ise derste gazete kupürleri kullanılmasından daha hoşnut olduğunu belirtmiştir. Öğrenci, gazete haberlerinin olayları daha ayrıntılı anlattığını, konuyu daha iyi anlamasını sağladığını belirtmiştir:

"En çok gazete haberlerini sevdim. Her şeyi daha detayl anlatiyor daha çok sevdim. Gazetede ev kazalarını birebir görmek, gerçek olması yüzünden daha etkileyiciydi." (Ö3)

Görsel materyaller öğrencilerin dikkatini çekmede, motive etmede, anlatılan konunun desteklenmesinde etkili olan materyallerdir (Ashaver ve Igyuve, 2013; 54-55; Çakır, 2007: 4-5; Daniel, 2013: 3813). Özellikle günümüzde öğrencilerin okumaya olan isteksizliği ya da yavaş okuyan ve okuduğunu anlamakta güçlük çeken öğrenciler için bu tür materyaller kurtarıcı görevi görmektedir. Yapılan çalışmada ise öğrencilerden biri dışında hepsinin kullanılan materyallerden en çok videoları sevdikleri ve beğendikleri görülmektedir. Bu durumun nedenleri ise öğrenciler arasında farklılık göstermektedir. Öğrencilerden bir kısmı okumayı sevmedikleri için videoları izlemeyi daha ilgi çekici bulmaktadır. Gazete ve kitapların yazılı araçlar olması nedeniyle videolar öğrenciler tarafindan daha farklı ve dikkat çekici bir araç olarak görülmektedir. Öğrencilerin bu görüşü incelendiğinde ise karşımıza hem olumlu hem olumsuz iki durum çıkmaktadır. Okumayı sevmeyen öğrencilere belirli şeyleri öğretmek için videoları kullanmak yararlı olabilmektedir. Ancak öğrencinin okumayı sevmemesi, onu hayat boyu olumsuz etkileyecek bir tutumdur. Özellikle derslerde karşılaşacağı sorunları video gibi araçlarla çözmesi öğrencinin okumaya olan olumsuz tutumunu daha da pekiştirebilir. Bu nedenle öğretmenin derste 
video kullanırken öğrencinin okuma alışkanlığına yönelik çalışmaların da üstünde durması gerekmektedir.

Öğrencilerin bir kısmı ise videoların herkes tarafindan kabul edilen en faydalı özelliklerinden birini vurgulamışlardır. Videolar bizim günlük hayatta karşılaşma, gezme ya da yaşama firsatımızın olmadığ 1 şeyleri görmemize ya da tecrübe etmemize aracılık etmektedir. Öğrenciler de videolar sayesinde görme imkânları olmayan müze gibi alanları, doğal afet gibi durumları ayrıntılı şekilde tanıma, anlama imkânı bulmaktadır. Özellikle Atatürk gibi çok duydukları ama bire bir karşılaşma imkânları olmayan, önemli kişilere ait eşyaları görmenin kendilerini duygulandırdıklarını belirtmişlerdir. Ayrıca bahsi geçen konuya dair bilgilerle beraber görsellerin de bulunması öğrencilerin konuyu daha iyi anlamasına yardımcı olmaktadır. Öğrencilere özellikle daha önce karşılaşmadıkları konularla ilgili olarak video izletmek konuyu zihinlerinde canlandırmaları açısından çok daha faydalı sonuçlar elde edilebilmesini sağlamaktadır. Hobbs (2006) ve Palma (2009) tarafından yapılan çalışmalarda da medya ürünlerinin kavramların, fikirlerin canlandırılmasında ve daha anlamlı hale getirilerek öğrenilmesinde etkili olduğu belirlenmiştir.

Öğrencilerin videolara olan olumlu tutumunun diğer bir nedeni ise videoların bilgisayarla olan bağlantısı olarak değerlendirilebilir. Yapılan birçok çalışmada kanıtlandığı gibi çocuklar ve gençler bilgisayar başında zaman geçirmekten büyük keyif almakta ve bu zamanın büyük çoğunluğunu eğlence amaçlı aktivitelere harcamaktadırlar (Patriarca, Di Giuseppe, Albano, Marinelli ve Angelillo, 2009, s. 8-9; Plowman, Stevenson, Stephen ve Mcpake, 2012, s. 36). Bu nedenle öğrencilerin bilgisayarla yapılan aktivitelere olan tutumu zaten izlemekten zevk aldıkları videoları daha da eğlenceli kılabilmektedir. Yani öğrencilerin bilgisayara karşı olan olumlu tutumları derse olan katılımlarını da arttırmada etkili olmaktadır.

Araştırma sürecinde yapılan gözlemlerde ise öğrencilerin videoları izlerken yaşadıkları duygu değişimi dikkat çekicidir. Öğrenciler Dünya'nın uzaydan görünüşüne yönelik olarak hayranlık duyabilmekte, pandomim videosunda eğlenebilmekte, Atatürk müzesi gezisinde ise duygulanabilmektedir. Bu nedenle de derste videoların kullanılması öğrencilerin ilgisini canlı tutabilmektedir. Ayrıca videolardaki çarpıcı görseller öğrencilerin merakını uyandırarak konu ile ilgili pek çok soru sormaya teşvik edebilmektedir. Gazete ve videoları dersin işlenişi sürecinde öğrencilerin tepkileri açısından değerlendirmek gerekirse videolar özellikle öğrencilerin daha önce karşılaşmadığı konular üzerinde kullanıldığ 1 için çok daha ilgi çekici gelebilmektedir. Ayrıca öğrencilerin pek çok duygusuna ve duyusuna hitap edebilmektedir. Videolar öğrencilere çok daha çarpıcı gelmekte bu nedenle öğrenciler üzerinde daha etkili olabilmektedir. Doeveling, Scheve ve Konijin (2010) çalışmalarında medya ürünlerinin toplum üzerindeki etkisini medyanın duygulara hitap edebilmesine bağlamışlardır. Böylece medya ürünleri aracılığı ile öğrenilen bilgilerin unutulmasının daha güç olduğu belirlenmiştir. Gazeteler ise öğrencilerin konuları günlük hayatları ile bağdaştırmasında etkili olmaktadır. Yapılan görüşmelerde öğrencilerin gazete haberlerini en az videolar kadar net bir şekilde hatırladıkları belirlenmiştir. Günlük hayata dönük yapılan haberler öğrencilerin konuları kendi yaşamları ile çok daha kolay bağdaştırmalarını sağlamıştır. Öğrenciler, gazetede okudukları haberler sayesinde çevrelerinde olup biten pek çok benzer olayı bağdaştırıp yorumlayabilmişlerdir.

\section{Öğrencilerin dersin işleniş sürecine yönelik görüşleri}

Bu başlıkta öğrencilerin dersin işleniş sürecine ve bu süreçte materyallerin kullanım amaçlarına yönelik görüşleri belirlenmeye çalışılmıştır. Yapılan görüşmelerde öğrencilerin kullanılan materyalleri çok sevdikleri ve ders sürecinde sıkılmadıkları anlaşılmaktadır. Öğrencilerden bazılarının ders işleme sürecindeki etkinlikleri kitaptaki etkinliklerle karşılaştırdıkları ve medya destekli etkinlikleri çok daha sevdikleri ve bu etkinlikler sayesinde daha iyi zaman geçirdikleri görülmektedir. Öğrencilerin konu ile ilgili düşünceleri aşağıdaki gibidir:

“Derste internetten faydalanmak çok güzel oluyor. Sadece kitaplar yeterli gelmiyor.” (Ö1) "Dersi böyle video ve fotoğraflarla işlemek daha güzel çünkü ders çok çabuk geçiyor, zevkli oluyor. Mesela zehirlenmelere karşı neler yapacağımızı öğrendik (Ö2). 
Gazetelerle ders işlemek daha güzel, çok daha fazla şey görebiliyoruz. Etkinlikler çok güzel." (Ö3)

"Bu şekilde ders işlemeyi daha çok sevdik, kitaptaki etkinliklere benzemiyor çok daha güzel. Benim bilgisayarı çok sevmem dersi sevmemi de etkiliyor." (Ö5)

"Kitaplar da güzel ama kitaplardakileri burada görmek daha güzel." (Ö6)

"Yaptığımız etkinlikler çok eğlenceliydi. Kitaplardaki resimler resim gibi olmuyor çizgi film şeyi gibi oluyor, sevmiyorum. Gerçek resimler daha dikkatimi çekiyor. Bu etkinliklerle gerçek olayları görüyoruz." (Ö9)

"Video ve gazeteler sayesinde sanki daha iyi anladim gibi hissettim, etkinlikler daha eğlenceliydi." (Ö10)

"Gazete haberleri sayesinde olayları öğreniyoruz. Dünyadan haberdar oluyoruz. Videolar da güzeldi, ders çok çabuk geçti.” (Ö12)

"Kitaplardakiler bazen çok uzun. Ama buradaki izlediklerimiz gördüklerimizde böyle şeyler yok." (Ö14)

"Kitaplardaki metinler çok slkıcı. Bu haberler ve videolarda daha eğlenceli olaylar var." (Ö15).

Kılavuz kitaplar, ders ve çalışma kitapları dersin işleniş sürecini kolaylaştırmak amacıyla öğretmene yardımcı olan materyallerdir. Bu materyallerin istenilen düzeyde faydalı olabilmesi için öğrencilerin düzeyine uygun olması, hazırlanan metin ve etkinliklerin öğrencilerin dikkatini çektiği kadar istenilen davranışları da kazandırması beklenmektedir. Kılavuz kitaplar ders sürecinin düzenlenmesinde yardımcı kaynak olarak kullanılırken, ders kitapları başvuru kaynağı, çalışma kitapları ise kazandırılmak istenilen becerilerin pekiştirilmesini amaçlamaktadır. Ancak özellikle ders kitabı inceleme konulu çalışmalara bakıldığında kitapların, birçok eleştiri ile karşı karşıya kaldığı görülmektedir. Ders kitaplarına yönelik yapılan eleştiriler incelendiğinde en fazla soyut kavramlara yer verilmesi, öğrenci seviyesine uygun olmaması gibi sorunlar göze çarpmaktadır (Yapıcı, 2004, s. 128-129).

Yapılan görüşmelerde ders kitabında aktarılan salt bilgi ile öğrencilerin konuları zihinlerinde canlandırma konusunda zaman zaman güçlükler çektikleri görülmektedir. $\mathrm{Bu}$ nedenle öğrencilerin özellikle ilk kez karşılaştıkları terimleri önce tanımaları sonrasında ise konu ile ilgili bilgi edinmeleri daha faydalı olabilmektedir. Özellikle somut işlemler döneminde bulunan öğrencilere yönelik ders kitaplarında sıklıkla gelişigüzel soyut kavramlara yer verilmesi öğrencilerin öğrenme güçlüğü yaşamasına neden olmaktadır. Bu durumun aşılabilmesi için öğretmenlerin kılavuz kitapta ve çalışma kitaplarındaki etkinlikleri bir kenara bırakarak yeni etkinlikler düzenlemesi ya da bu etkinlikleri çeşitli materyallerle desteklemesi faydalı olacaktır. $\mathrm{Bu}$ faydanın sağlanmasında öğrencilerin verdikleri yanıtlarda medya destekli ürünlerin çok etkili olduğu görülmektedir. Özellikle medya araçlarının kolay ulaşılabilir olması, öğrenciler tarafindan sevilmesi ayrıca konuyu somutlaştırması ders kitaplarındaki güçlüklerin ortadan kaldırılmasında etkili olmaktadır. Mayer (2003) ve Michelic (2001) tarafindan yapılan çalışmalarda da sözcüklerin somut işlemler dönemindeki çocuklara kavramların öğretilmesinde yetersiz kaldığını belirlemişlerdir. Bu nedenle çalışmalarında kavramları öğretirken medya araçları kullanmışlardır. Yapılan çalışmalarda medya araçları kullanmanın öğrenci başarısında artış sağladığı ortaya çıkmıştır.

Yapılan çalışmada medya ürünlerinin etkili olduğu diğer bir konu yapılan etkinliklerdeki yazma çalışmalarını kolaylaştırmasıdır. Öğretim programında yazmaya yönelik olan etkinliklerde öğrencilerin fikirleri çok daha düzenli ve etkili bir şekilde sundukları gözlenmiştir. $\mathrm{Bu}$ durumun oluşmasında farklı medya ürünlerinin kullanılmasının hem konuyu somutlaştırması hem de olaylara farklı açılardan bakılmasını sağlamasının etkili olduğu düşünülmektedir.

\section{Öğrencilerin ̈̈ğretim programı sonrası sürece yönelik görüşleri}

Bu başlıkta öğrencilerin, öğretim programı tamamlandıktan sonraki sürece yönelik düşünceleri belirlenmeye çalışılmıştır. Öğrencilerin yapılan görüşmelerde Hayat Bilgisi dersinin işleniş sürecindeki değişikliğin farkında olduğu görülmektedir. Buradan yola çıkılarak öğrencinin 
gözünden dersin işleniş sürecinde yaşanan sıkıntıların belirlenmesi ve bundan sonraki sürecin daha kusursuz hale getirilmesi amaçlanmaktadır. Öğrencilerin konu ile ilgili düşünceleri aşağıdaki gibidir:

"Dersi böyle işlemek daha güzel çünkü ders çok çabuk geçiyor, zevkli oluyor. Akıllı tahtalar, tabletler gelsin diğer derslerde de bu şekilde ders işleyelim." (Ö2)

"Bu şekilde ders işlemek daha güzel. Daha fazla bilgisayarla ders işleyelim." (Ö3)

"Bu şekilde ders işlemeyi eskisine tercih ederim. Hep dersler bu şekilde olsun." (Ö4)

"Bundan sonra videolar daha fazla olsun." (Ö5)

"Başka derslerde de video, gazete kullanmaya başlayalım." (Ö7)

"Kitaplardaki etkinlikler çok uzun oluyor, çok yazma var. Bu etkinlikleri yapmak daha kolay. Yine bu şekilde devam edelim." (Ö8)

"İkisi birlikte olsun, sadece kitaplar değil videolar da olmaya devam etsin." (Ö9)

"Videolar ve gazeteleri kullanmaya devam edelim. Tablet dağıtsınlar. Ödevleri hazırlarken de video, gazetelerden yararlanalim, sinifta sunalım." (Ö11)

"Çalışma kitabındaki etkinlikler yerine bunlardan [video, gazete, fotoğraflar] kullanmaya devam edelim.” (Ö12)

"Bütün derslerde kullanmaya başlayalım [video, gazete, fotoğraf]. " (Ö13)

"Bazen okuduğumu anlamak zorlaşlyor, o yüzden diğer derslerde de görsellerden yararlanalım." (Ö15)

Ders işleme süreci açısından incelendiğinde öğrencilerin genel olarak bu süreçte bir sorun yaşamadıkları yapılan görüşmelerden anlaşılmaktadır. Öğrencilerin görsel ağırlıklı materyallere yönelik ilgisi dikkat çekmektedir. Öğrenciler sıklıkla okudukları metinlerin görsellerle zenginleştirilmesini ve desteklenmesini istediklerini vurgulamaktadırlar. Ayrıca programın öğrenciler tarafından ilgi çekici olduğunu anlamamızı sağlayan en önemli noktalardan biri diğer derslerde de bu tür materyallerin kullanılması yönündeki istekleridir. Eğitim sistemimizin temel bir sorunu olarak gösterilebilecek nokta ise bu ve diğer başlıklardaki yanıtlar arasında da sıklıkla görebildiğimiz öğrencilerin okuduğunu anlama noktasında yaşadığı sıkıntılardır. Öğrencilerin okuduğunu anlamakta güçlük çekmesi derslerde görsellerden faydalanılmasını zorunlu hale getirmektedir. Bu durum ilkokulun ilk basamaklarında video, fotoğraf gibi görsel araçlarla aşılsa da eğitim sürecinin ilerleyen basamaklarında bu sorun devam ederse öğrencilerin akademik başarılarında ciddi düşüşler yaşanması söz konusu olabilmektedir. Çünkü okuduğunu anlamayan ögrenciler sadece sözel derslerde değil sayısal derslerde de okuduklarını anlayamadıkları için çok basit yönergeleri uygulamakta ya da soruları cevaplamakta başarısız olabilmektedirler. Elbette ki medya ürünleri sayesinde dersin daha ilgi çekici ve anlaşılır hale gelmesi öğretmenlerin işini kolaylaştıracak bir durumdur. Ancak öğretmenlerin, medya ürünlerini okuduğunu anlama problemini çözmekten ziyade soyut kavramların somutlaştırılması ya da dersi sıkıcılıktan kurtararak öğrencileri güdüleme amaçlı kullanması daha faydalı olacaktır. Hibbing ve Erickson (2003) tarafindan yapılan çalışmada öğrencilerin yaptıkları okumalar görsel ağırlıklı medya ürünleri ile desteklenmiş ve öğrencilerin okuduklarını anlama düzeyinde artış gözlenmiştir.

\section{Sonuç ve Tartışma}

Araştırma sonucunda “Medya Destekli Hayat Bilgisi Öğretim Programı”nın öğrencilerin öğrenmesini olumlu yönde etkilediği görülmektedir. Yapılan çalışma sonucunda deney grubunda yer alan öğrencilerin ön test ve son test puanları arasında anlamlı farklılık olduğu görülmektedir. Yani yapılan son test sonucunda uygulanan "Medya Destekli Hayat Bilgisi Öğretim Programı"nın, öğrencilere istenilen kazanımları kazandırmada etkili olduğu ortaya çıkmaktadır.

Kontrol grubu üzerinde yapılan son test uygulaması sonucunda öğrencilere uygulanan ön test ve son test puanları arasında anlamlı farklılık olduğu görülmektedir. Kontrol grubunda meydana gelen anlamlı farkl1lık göstermektedir ki öğrencilere uygulanan geleneksel eğitimöğretim süreci de kazanımların kazandırılmasında etkili olmaktadır. 
“Medya Destekli Hayat Bilgisi Öğretim Programı”nın etkililiğini sınamak amacıyla yapılan deney ve kontrol grubunun karşılaştırıldığı son test sonucunda ise deney grubu lehine anlamlı farklılık ortaya çıkmıştır. Yapılan çalışmada uygulanan son test sonucunda "Medya Destekli Hayat Bilgisi Öğretim Programı"nın belirlenen kazanımların kazandırılmasında geleneksel eğitim-öğretim programına oranla daha etkili olduğu söylenilebilir. Koning ve diğerleri (2007, s. 741) tarafindan yapılan araştırmada medya destekli öğrenmenin öğrencilerin zihinsel çabalarını arttırdığı ve bilginin transferini kolaylaştırdığı ortaya çıkmıştır. Böylece medyanın öğrencilere aktarılmak istenilen bilgilerin öğretilmesinde etkili bir araç olduğu belirlenmiştir.

Whatley ve Ahmad (2007) tarafindan yapılan çalışmada videolar öğrenilen konuların tekrar edilmesinde ve öğrencilerin ölçme sürecine hazırlanmasında kullanılmıştır. Araştırma sonucunda öğrenilen konuların videolar ile desteklenerek tekrar edilmesinin öğrenmeyi ve öğretmeyi desteklediği ortaya çıkmıştır. Pitrik ve Holzinger (2002, s. 160) tarafından yapılan çalışmada da medya ürünlerinin öğrenme üzerinde olumlu etki yaptığı görülmüştür. Derste medya ürünleri kullanmanın öğrenci merkezli öğretim yapılmasını sağladığı, grup içi etkileşimi arttırdığı, öğrencilerin daha derinlemesine bilgi edinmesini sağladığı görülmüştür. Carver ve diğerleri (1999, s. 33) tarafından yapılan çalışmada farklı medya ürünleri kullanmanın öğrenmeyi bireyselleştirdiği görülmüştür. Medya ürünleri sayesinde öğrencilerin kendi öğrenme biçimlerine uygun materyaller bulabildiği, bireysel farklılıkların öğrenme sürecinde desteklenmesinin sağlandığı görülmüsstür. Derste medya ürünleri kullanmanın öğrencilerin öğrenmelerinde olumlu düzeyde etkili olduğu görülmüştür. Owston (1997, s. 31) tarafından yapılan çalışmada derste medya kullanmanın öğrenmeyi desteklediği, geleneksel bilgiyi farklı şekillerde sunabildiği için farklı öğrenme stillerine hitap ettiği ortaya çıkmıştır. Böylece öğrencilerin birçok alanda daha başarılı ve meraklı oldukları gözlenmiştir.

Öğrenme-öğretme sürecinde öğretmenlerin en çok güçlük yaşadıkları konulardan biri de öğrencilerin öğrendikleri bilgileri unutabilmesidir. Özellikle aşamalılık gösteren derslerde öğrencilerin bir önceki konuya yönelik ön bilgileri ayrıca önem taşımaktadır. $\mathrm{Bu}$ nedenle araştırmada medya destekli öğretim programının öğrencilerin öğrendikleri bilgilerin kalıcılığına etkili olup olmadığı ölçülmeye çalışılmıştır. Deney grubunun elde ettiği sonuçlardan yapılan son test ve kalıcılık testi karşılaştırılmasında anlamlı farklılık bulunmamaktadır. Yani deney grubundaki öğrencilerin öğrendikleri bilgilerde artış gözlenmediği gibi dikkat çekici ya da anlamlı bir fark yaratacak şekilde "unutma" söz konusu olmamaktadır.

Kontrol grubunun son test ve kalıcılık testi sonuçları karşılaştırıldığında iki test arasında anlamlı farklılık görülmektedir. Kalıcılık testi sonuçlarında öğrencilerin aldıkları puanlarda düşüş görülmektedir. $\mathrm{Bu}$ nedenle karşılaştırma sonucunda son test lehine anlamlı farklılık görülmektedir. Yani kontrol grubundaki öğrencilerin öğrendikleri bazı bilgileri unuttukları belirlenmiştir. Deney ve kontrol grubunun kalıcılık testi başarı puanları karşılaştırıldığında deney grubu lehine anlamlı farklılık görülmektedir. Yapılan kalıcılık testi sonucunda başarı puanları karşılaştırıldığında ise deney grubunun test sonucunda daha yüksek puanlar elde ettiği görülmektedir. Bu durum "Medya Destekli Hayat Bilgisi Öğretim Programı"nın öğrenmede kalıcılığın sağlanmasında daha etkili olduğunu göstermektedir. Butler ve diğerleri (2009) tarafindan yapılan çalışmada derste film izleyerek yapılan öğrenmelerin sadece metin ile gerçekleşen öğrenmelere oranla çok daha kalıcı olduğu belirlenmiştir. Öğrencilere öğretilmek istenilen konu film gibi etkili medya araçları ile desteklendiğinde öğrencilerin konuyu çok daha uzun süre hatırladıkları belirlenmiştir. Mayer ve Moreno (2002, s. 116-117) tarafindan yapılan çalışmada da medya araçları kullanmanın öğrenmenin kalıcılığı üzerinde daha etkili olduğu ortaya çıkmıştır. Yapılan çalışmada öğrenme sürecinde öğrencilerin birden fazla duyusuna hitap eden araçlar kullanmanın öğrenmenin kalıcılığı üzerinde daha etkili olduğu belirlenmiştir. Mayer (1999) tarafinda yapılan çalışmada ise öğrencilerin fen ve matematik gibi güçlük çektikleri alanlarda medya araçları kullanılmıştır. Çalışma sonucunda bu tür araçların öğrencilerin öğrendikleri bilgileri transfer etmesini kolaylaştırdığı ve öğrenmede kalıcıllğ 1 arttırdığ 1 belirlenmiştir. 


\section{Kaynaklar}

Aksaçlıŏlu, A. G. ve Yılmaz, B. (2007). Öğrencilerin televizyon izlemeleri ve bilgisayar kullanmalarının okuma alışkanlıklarına etkisi. Türk Kütüphaneciliği Dergisi, 21(1), 3-28.

Alver, F. (2005). Neil Postman'ın çocukluğun yok oluşu sürecinde iletişim teknolojisi eleştirisinin eleştirisi. İletişim Araştırmaları, 2(2), 129-141.

Arslan, M. ve Adem, E. (2010). Yabancılara Türkçe öğretiminde görsel ve işitsel araçların etkin kullanımı. Ankara Üniversitesi Dil Dergisi, 147, 63-86.

Ashaver, D. ve Igyuve, S. M. (2013). The use of audio-visual materials in the teaching and learning process in colleges of education in Benue State Nigeria. IOSRJournal of Research\&Method in Education, 1(6), 44-55.

Belet, Ş. D. (1999). İlköğretim kurumlarında uygulanan hayat bilgisi programının değerlendirilmesi. Anadolu Üniversitesi Eğitim Fakültesi Dergisi, 9(1-2), 77-79.

Berk, R. A. (2009). Multimedia teaching with video clips: Tv, movies, youtube, and mtv in the college classroom. International Journal of Technology in Teaching and Learning, 5(1), $1-21$.

Butler, C. A., Zaromb, F. M., Lyle, K. B. ve Roediger, H. L. (2009). Using popular films to enhance classroom learning: The good, the bad, and the interesting. Association for Psychological Science, 20(9), 1161-1168.

Carver, C. A., Howard, R. A. ve Lane, W. D. (1999). Enhancing student learning through hypermedia course and incorporation of student learning styles. IEEE Transactions on Education, 42(1), 33-38.

Creswell, J. W. (2003). Rsearch desing: Qualtative, quantitative, and mixed methods approaches. London: Sage Publications.

Creswell, J. W. ve Plano Clark, V. L. (2007). Desingning and conducting mixed research. Thousand Oaks, CA: Sage.

Çakır, G. (2007). Yeni Hayat Bilgisi programında yer alan kazanımların önerilen etkinlikler çerçevesinde gerçekleştirilebilme düzeyinin belirlenmesi (Yayımlanmış yüksek lisans tezi). Firat Üniversitesi, Sosyal Bilimler Enstitüsü, Elazığ.

Daniel, J. (2013). Audio-visual aids in teaching of English. International Journal of Innovative Research in Science Engineering and Technology, 2(8), 3811-3814.

Demir, S. (2006). Illköğretim programında okutulmakta olan Hayat Bilgisi derslerinin, ögrencileri fen bilgisi derslerine hazırlamadaki etkileri (Yayımlanmış yüksek lisans tezi). Ondokuz Mayıs Üniversitesi, Eğiitm Fakültesi, Samsun.

Doeveling, K., Scheve, C. V. ve Konijin, E. A. (2010). Handbook of emotions and mass media. London: Routledge, Taylor\&Francis.

Doğan, N. K. (2006). Televizyon programlarındaki şiddet öğelerinin çocuklar üzerindeki etkisi ve ebeveynlerin tutumlarının belirlenmesine yönelik araştırma. İstanbul Üniversitesi Iletişim Fakültesi Dergisi, 26, 1-15.

Doğutaş, A. (2013). Medya şiddetinin çocuklar üzerindeki etkisi. Boğaziçi Üniversitesi Eğitim Fakültesi Dergisi, 2(1), 107-126.

Duplass, J. A. (2010). Teaching elementary social studies: Strategies, standarts, and internet resources. Boston: Cengage Learning.

Farris, P. J. (2015). Elementary and middle school social studies an interdisciplinary, multicultural approach. Illinois: Waveland Press.

Erjem, Y. ve Çağlayandereli, M. (2006). Televizyon ve gençlik: Yerli dizilerin gençlerin model alma davranışı üzerindeki etkisi. Cunhuriyet Üniversitesi SosyalBilimler Dergisi, 30(1), $15-30$.

Hibbing, A. N. ve Erickson, J. L. R. (2003). A picture is worth a thousand words: Using visual images to improve comprehension for middle school struggling readers. The Reading Teacher, 56(89), 758-770.

Hobbs, R. (2006). Non-optimal uses of the video in the clasroom. Learning, Media and Technology, 31(1), 35-50. 
Holden, J. T. ve Westfall, P. J. (2005). An instructional media selection guide for distance learning. United States Distance Learning Association Report.

Hsin Yih, C. S. (2010). Using video-based anchored instruction to enchance learning: Taiwan's experience. British Journal of Educational Technology, 31(1), 57-69.

İrkin, A. Ç. (2012). Çocukların gelişim süreci ve televizyonun etkileri (Yayımlanmamış Uzmanlık Tezi). Radyo Televizyon Üst Kurulu, Ankara.

İşler, A. (2003). Yazılı ders materyallerinde illüstrasyon kullanımının yeri ve önemi. Milli Ĕgitim Dergisi, 157.

Kabapınar, Y. (2002). İlköğretim hayat bilgisi ve sosyal bilgiler öğretiminde kullanılan ders kitapları ve öğretim materyalleri açısından Türkiye ve İngiltere örnekleri. Kuram ve Uygulamada Ĕgitim Bilimleri, 2(1), 249-270.

Kabapınar, Y. (2007). Ilköğretimde hayat bilgisi ve sosyal bilgiler öğretimi. Ankara: Maya Akademi.

Karaaslan, İ. (2015). Dijital oyunlar ve dijital şiddet farkındalığı: Ebeveyn ve çocuklar üzerinde yapılan karşılaştırmalı bir analiz. Uluslararası SosyalAraştırmalar Dergisi, 8(36), 806818.

Karakaş, A. ve Karaca, G. (2011). Yabancı dil öğretiminde resmin materyal olarak kullanımı ve önemi. Yaşadıkça Eğitim Dergisi, 110, 14-19.

Kaya, K. ve Tuna, M. (2008). İlköğretim çağındaki çocukların sosyalleşmesinde televizyonun etkisi. Süleyman Demirel Üniversitesi Fen Edebiyat Fakültesi Sosyal Bilimler Dergisi, $17,159-182$.

Knill, O. (2007). Benefits and risks of media and technology in the classroom. ICTCM Conference, Boston.

Koning, B. B., Tabbers, H. K., Rikers, R. M. J. P. ve Paas, F. (2007). Attention cueiing as means to enchance learning from animation. Applied CognitivePsychology, 21, 731-746.

Kozma, R. (1994). Will media influence learning?: Reframing the debate. Educational Technology Research and Development, 42(2), 7-19.

Köken, N. (2003). Çocuk ve Hayat Bilgisi. Gazi Üniversitesi Kırşehir Eğitim Fakültesi Dergisi, $4(1), 15-27$.

Mayer, R. E. (1999). Multimedia aids to problem solving transfer. International Journal of Educational Research, 31, 611-623.

Mayer, R. E. (2003). The promise of multimedia learning: Using the same instructional design methods across different media. Learning and Instruction, 13,125-139.

Mayer, R. E. ve Moreno, R. (2002). Aids to computer based multimedia learning. Learning and Instruction, 12, 107-119.

McKay, S. L. (2012). Teaching materials for English as an international language. A. Matsuda, (Yay. haz.), Principles and practices of teaching English as aninternational language. Bristol: Multilingual Matters.

MEB (2013). Fatih Projesi. Erişim adresi: http://fatihprojesi.meb.gov.tr/tr/index.php

Sönmez, V. (2010). Hayat Bilgisi ögretimi ve ögretmen kılavuzu. Ankara: Anı Yayıncılık.

Owston, R. D. (1997). The World wide web: A technology to enchance teaching and learning? Educational Researcher, 26(2), 27-33.

Östlund, U., Kidd, L., Wengstörm, W. ve Rowa-Dewar, N. (2011). Combining qualitative and quantative research within mixed method research designs: A methodological review. International Journal of Nursing Studies, 48, 369-383.

Özdemir, M. (1998). Hayat Bilgisi ögrenme ve ögretme etkinlikleri. Ankara: Pegem Yayıncılık.

Palma, M. T. (2009). Teaching geography using films: A proposal. Journal of Geography, 108(2), 47-56.

Patriarca, A., Di Giuseppe, G., Albano, L., Marinelli, P. ve Angelillo, I. F. (2009). Use of television, videogames, and computer among children and adolescents in Italy. BMC Public Health, 9(139), 1-10.

Pitrik, R. M. ve Holzinger, A. (2002). Student-centered teaching meets new media: Concept and case study. Educational Technology\&Society, 5(4), 160-172. 
Plowman, L., Stevenson, O., Stephen, C. ve Mcpake, J. (2012). Preschool children's learning with technology at home. Computers \& Education, 59, 30-37.

Purcell, K., Heaps, A., Buchanan, J. ve Friedrich, L. (2013). How teachers are using technology at home and in their classrooms. National Writing Project, Pew Resarch Centers's Internet\&American Life Project.

RTÜK (2013). Türkiye'de çocukların medya kullanma alışkanlıkları araştırması. Radyo ve Televizyon Üst Kurulu Kamuoyu Yayın Araştırmaları ve Ölçme Dairesi Başkanlığı, Ankara.

Schoenfeld, A. H. (2002). Making mathemetics work for all children: Issues of standarts, testing, and equity. American Educational Research Association, 31(1), 13-25.

Simo, P., Fernandez, V., Algaba, I., Salan, N., Enache, M., Albareda-Sambola, ... ve Rajadell, M. (2010). Video stream and teaching channels: Quantitative analysis of the use of lowcost educational videos on the web. Procedia Social and Behavioral Sciences, 2, 29372941.

Sözer, E. (2001). Öğretimde strateji, yöntem ve teknikler. M. Gültekin (Yay. haz.), Öğretimde planlama ve değerlendirme. Eskişehir: Anadolu Üniversitesi Açıköğretim Fakültesi Yayınları.

Tahiroğlu, A. Y., Çelik, G. G., Bahalı, K. ve Avcı, A. (2010). Medyanın çocuk ve gençler üzerine olumsuz etkileri; şiddet eğilimi ve internet bağımlı̆̆. YeniSymposium, 48, 19-30.

Tanrı̈ğgen, A. (2005). Hayat Bilgisi ve Sosyal Bilgiler öğretimi etkili vatandaş yetiştirme. A. Tanrı̈̈̆gen, (Yay. Haz.), Hayat Bilgisi ve Sosyal Bilgiler öğretimi, içinde. İstanbul: Lisans Yayıncilık.

Tekindal, S. (2005). Hayat Bilgisi öğretim program. C. Öztürk ve D. Dilek, (Yay. haz.), Hayat Bilgisi ve Sosyal Bilgiler ögretimi, içinde. Ankara: Pegem A Yayıncılık.

Whatley, J. ve Ahmad, A. (2007). Using video to record summary lectures to aid students' revision. Interdisciplinary Journal of E-Learning and LearningObjects, 3(1), 185-196.

Yapıc1, M. (2004). İlköğretim I. kademe ders kitaplarının öğrenci düzeyine uygunluğu. Afyon Kocatepe Sosyal Bilimler Enstitüsü Dergisi, 6(1), 121-130.

\section{Extended Abstract \\ Introduction}

Since the media tools have become widespread, the media effect has always been debated. Among the populations, where the media effect is at the highest level, children and youth constitute an important portion (Tahiroğlu et al., 2010; Aktaş \& Altunbaş, 2011). In many of the studies, the interest of young people regarding the media and the fact that they are influenced by the media in different ways can be easily seen (Aktaş \& Altunbaş, 2011; Erjem \& Çağlayandereli, 2006). But, when the contucted studies are considered, it can also be seen that they have developed a critical point of view towards the negative effects of media rather than its positive effects. It is of course not surprising that uncontrolledly leaving the children and youth to the media that should be considered as business organizations would have such results. However, it should also be considered that the media effect is an important tool that can also be used for teaching certain values in a planned manner. In this study, it was aimed to have children to attain certain concepts and values of media effect, which has been proved many times, through social studies lesson in $3^{\text {rd }}$ grade.

\section{Method}

For this purpose, a 6-week educational program was designed. First, the behaviors, which were planned to achieve, were selected by examining the attainments of Social Studies Program. After selecting the achievements, the lesson plans were designed, and the media tools (videos, photos, newspaper clippings, and etc.) to construct the backbone of the program were determined. The media tools and lesson plans were submitted for the opinions of 3 class teachers and 5 academicians. The modifications were executed in parallel with the general suggestions. Moreover, the success tests were prepared in order to determine the study groups for the 
measurement of pre-test post-test and permanence. Preliminary implementation was performed in order to more accurately observe the deficiencies of teaching program that was prepared. As a result of the preliminary tests applied to students, the study and control groups of preliminary study were determined. As a result of the preliminary implementation performed, the lesson programs were given their final form, and then the main implementation was initiated. Firstly, the study and control groups were determined in accordance with the results of preliminary test. The study group was given totally 24 hours of educational program for 6 weeks, while control group received normal educational program during this period. While implementing the educational program, open-ended observations were utilized in order to reveal the opinions of students regarding the lesson program. After completing the program, semi-structured interviews were employed in study group, and it was aimed to determine the opinions of students about the process of implementation of the program as well as the activities. Moreover, at the end of the program, by implementing the post-test and memorability test in control and study groups, it was aimed to determine if the educational program created any significant difference between the groups.

\section{Result and Discussion}

When the pre-test and post-test results of study group were compared, it was seen that there was a significant difference in favor of post-test results. Moreover, when the scores of the control group in pre-test and post-test were compared, it was also seen that there was a significant difference in favor of post-test results. Given the results of analyses, it can be seen that both of the lesson programs were efficient. In order to determine the effect of media-supported education program in proportion to normal educational process, the post-test scores of study and control groups were compared, and a significant difference in favor of study group was found. In this case, it can be seen that the media-supported education program is more efficient than the normal program. When the post-test and memorability test results of study group were compared, it was determined that there was non-significant difference between the scores. Thus, it can be seen that the implemented program is efficient in ensuring the memorability of knowledge. When the mean scores of control group in post-test and memorability tests, a significant difference in favor of post-test scores was found. Therefore, it can be seen that the normal educational program is not effective at desired level in ensuring the memorability of knowledge that was taught. As a result of the analyses performed in order to determine if there is a significant difference in mean scores of groups in memorability test, a significant difference in favor of study group was found. The first attention-grabbing finding throughout the interviews and observations with study group students was that the use of media tools in lessons was considered as a motivation for the students. It can be thought that the interest of students towards the media tools in their daily lives might play an effective role in this situation. Students expressed that they have experienced difficulties in learning the situations or the events that they cannot experience in their classroom environment or in their daily lives when they are just explained verbally or in written, and also that they have difficulties in imagining those phenomena in their minds. They also stated that images and videos make it significantly easier to imagine the cases. Moreover, the students having low reading rate expressed that they conceived the topic more easily. It was observed that the interest of students in printed-media tools and their motivations for the lessons designed based on these tools were lower. It can be thought that the similarity between these media tools and books might play a significant role in this relationship. However considering teaching the lesson, it was observed that the students provided various examples for the topic from their environments and they presented the phenomena very explanatorily. It was seen that vast variety of media products was effective in keeping the attention of students alive in lesson. Short duration of elementary school students' attention and the fact that they feel bored very quickly might require the utilization of many materials at the same time in lessons. The course books, at least nowadays, cannot provide any solution for this problem. However, when the appropriate media tools are utilized, various materials such as videos, photos, music, and printed-media can be effectively employed synchronously. One of the unexpected results of this study is that the utilization of media tools in lessons positively influenced the writing skills of students. The utilization of various media tools 
Medya Destekli Öğretimin Hayat Bilgisi Dersinde Akademik Başarıya ve Öğrenmede Kalıcılığa

Etkisi

while presenting the ideas allows the students to look at the events from different perspectives and to present these ideas more explanatorily. 